\title{
Pharmacokinetic characterization of fluorocoxib $D$, a cyclooxygenase-2-targeted optical imaging agent for detection of cancer
}

\author{
Maria Cekanova, ${ }^{\mathrm{a}, \mathrm{b}, *}$ Sony Pandey, ${ }^{\mathrm{a}}$ Shelly Olin, ${ }^{\mathrm{a}}$ Phillip Ryan, ${ }^{\mathrm{a}}$ \\ Jennifer E. Stokes, ${ }^{a}$ Silke Hecht, ${ }^{\text {a }}$ Tomas Martin-Jimenez, \\ Md. Jashim Uddin, ${ }^{d}$ and Lawrence J. Marnett ${ }^{d}$

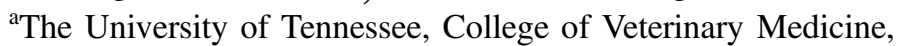 \\ Department of Small Animal Clinical Sciences, Knoxville, Tennessee, United States \\ ${ }^{b}$ The University of Tennessee, UT-ORNL Graduate School of Genome, Science and Technology, \\ Knoxville, Tennessee, United States \\ ${ }^{c}$ The University of Tennessee, College of Veterinary Medicine, \\ Department of Biomedical and Diagnostic Sciences, Knoxville, Tennessee, United States \\ ${ }^{\mathrm{d}}$ Vanderbilt University School of Medicine, Vanderbilt Institute of Chemical Biology, \\ Center for Molecular Toxicology and Vanderbilt-Ingram Cancer Center, \\ A. B. Hancock, Jr., Memorial Laboratory for Cancer Research, Departments of Biochemistry, \\ Chemistry and Pharmacology, Nashville, Tennessee, United States
}

\begin{abstract}
Significance: Fluorocoxib D, $N$-[(rhodamin-X-yl)but-4-yl]-2-[1-(4-chlorobenzoyl)-5-methoxy2-methyl-1H-indol-3-yl]acetamide, is a water-soluble optical imaging agent to detect cyclooxygenase-2 (COX-2)-expressing cancer cells.

Aim: We evaluated the pharmacokinetic and safety properties of fluorocoxib D and its ability to detect cancer cells in vitro and in vivo.

Approach: Pharmacokinetic parameters of fluorocoxib D were assessed from plasma collected at designated time points after intravenous administration of $1 \mathrm{mg} / \mathrm{kg}$ fluorocoxib $\mathrm{D}$ in six research dogs using a high-performance liquid chromatography analysis. Safety of fluorocoxib D was assessed for 3 days after its administration using physical assessment, complete blood count, serum chemistry profile, and complete urinalysis in six research dogs. The ability of fluorocoxib $\mathrm{D}$ to detect COX-2-expressing cancer cells was performed using human 5637 cells in vitro and during rhinoscopy evaluation of specific fluorocoxib $\mathrm{D}$ uptake by canine cancer cells in vivo.
\end{abstract}

Results: No evidence of toxicity and no clinically relevant adverse events were noted in dogs. Peak concentration of fluorocoxib D $(114.8 \pm 50.5 \mathrm{ng} / \mathrm{ml})$ was detected in plasma collected at $0.5 \mathrm{~h}$ after its administration. Pretreatment of celecoxib blocked specific uptake of fluorocoxib D in COX-2-expressing human 5637 cancer cells. Fluorocoxib D uptake was detected in histologyconfirmed COX-2-expressing head and neck cancer during rhinoscopy in a client-owned dog in vivo. Specific tumor-to-normal tissue ratio of detected fluorocoxib D signal was in an average of $3.7 \pm 0.9$ using Image $\mathbf{J}$ analysis.

Conclusions: Our results suggest that fluorocoxib D is a safe optical imaging agent used for detection of COX-2-expressing cancers and their margins during image-guided minimally invasive biopsy and surgical procedures.

(C) The Authors. Published by SPIE under a Creative Commons Attribution 4.0 Unported License. Distribution or reproduction of this work in whole or in part requires full attribution of the original publication, including its DOI. [DOI: 10.1117/1.JBO.25.8.086005]

Keywords: fluorocoxib; optical imaging; cyclooxygenase-2; pharmacokinetic parameters; dog with naturally occurring cancer; biopsy.

Paper 200044R received Feb. 19, 2020; accepted for publication Aug. 11, 2020; published online Aug. 28, 2020.

*Address all correspondence to Maria Cekanova, E-mail: mcekanov@utk.edu 


\section{Introduction}

Optical imaging agents have been synthesized and validated for detection of cancer to guide minimally invasive biopsy or open surgical resections. ${ }^{1-8}$ These imaging platforms include small molecules, peptides, antibodies, nanoparticles, or affibody labeled with fluorescent dyes. ${ }^{1-8}$ Optimal targeted contrast agents for clinical application must exhibit safe toxicity profile and have rapid tumor uptake, high tumor-to-background ratio, high specificity and sensitivity, as well as long-term stability. ${ }^{1}$

Cyclooxygenase-2 (COX-2) protein is induced in inflammatory and cancer cells, but not in normal epithelial cells, ${ }^{9-20}$ which makes $\mathrm{COX}$ as an attractive marker in detection of cancer cells. $^{21-28}$ Derivatives of nonsteroidal anti-inflammatory drugs (NSAIDs) labeled with 5-carboxyX-rhodamine dyes (fluorocoxibs) $\left(\lambda_{\mathrm{ex}}=580 \mathrm{~nm}\right.$ and $\lambda_{\mathrm{em}}=605 \mathrm{~nm}$ ) have been synthesized and evaluated as optical imaging agents for detection of COX-2 in cancer cells. ${ }^{29,30}$ We and others have proven the selective and specific uptake of fluorocoxib A by COX-2-expressing cancer cells in vitro and in vivo. ${ }^{31-38}$ We have also shown that fluorocoxib A has the ability to not only detect the cancer but also has an ability to monitor the tumor's responses to therapy. ${ }^{32}$ Fluorocoxib D, $N$-[(rhodamin-X-yl)but-4-yl]-2-[1-(4-chlorobenzoyl)-5-methoxy-2-methyl-1H-indol-3-yl]acetamide, is a decarboxy analog of fluorocoxib $\mathrm{A}$, and a derivative of indomethacin that selectively binds and inhibits the COX-2 enzyme. ${ }^{39}$ It has been shown that fluorocoxib D has improved water solubility as compared to fluorocoxib $\mathrm{A}^{39}$ in order to progress clinical translation of this COX-2-targeted optical imaging agent.

Validation of imaging and therapeutic agents mostly relies on the whole-body imaging approach using the rodent cancer models, which is a limiting factor in the effective translation of imaging agents to human clinical applications. Companion animals with naturally occurring cancers are more appropriate animal models used for a validation of imaging agents and therapeutics. ${ }^{38,40-46}$ Spontaneous cancers in companion dogs offer a unique model for human cancer biology. ${ }^{38,40-46}$ Thus, to further evaluate the promising new optical imaging fluorophore, fluorocoxib D, we investigated its safety and pharmacokinetic properties in healthy research dogs. Further, we validated the selective uptake of fluorocoxib D by COX-2-expressing human cancer cells in vitro. We also confirmed specific uptake of fluorocoxib D in histology-confirmed COX-2-expressing cancer during image-guided biopsy procedure using rhinoscopy in clientowned dog in vivo.

\section{Material and Methods}

\subsection{Fluorocoxib $D$}

Fluorocoxib D was synthesized as previously described by Uddin. ${ }^{39}$ The chemical structures of indomethacin, 5-carboxy-rhodamine, and fluorocoxib D along with their potencies as COXinhibitors are shown in Fig. 1 and Table 1.

In our in vivo experiments, fluorocoxib D was dissolved in dimethyl sulfoxide/ethanol/ propylene glycol/saline solution to final concentration of $5 \mathrm{mg} / \mathrm{ml}$ under sterile conditions and filtered using a $0.1-\mu \mathrm{m}$ pore size filter.

\subsection{Antibodies and Other Reagents}

Antibody for COX-2 was obtained from Cayman Chemical Corporation (Ann Arbor, Michigan), and antibody for Ki67 was purchased from Dako (Carpinteria, California). All other chemicals and reagents were purchased from Thermo Fisher Scientific (Pittsburgh, Pennsylvania), unless otherwise specified.

\subsection{Human Cancer Cell Line}

Human 5637 bladder cancer cells were purchased from American Type Culture Collection (ATCC, Manassas, Virginia). Human 5637 cancer cells were maintained in RPMI-1640 media 

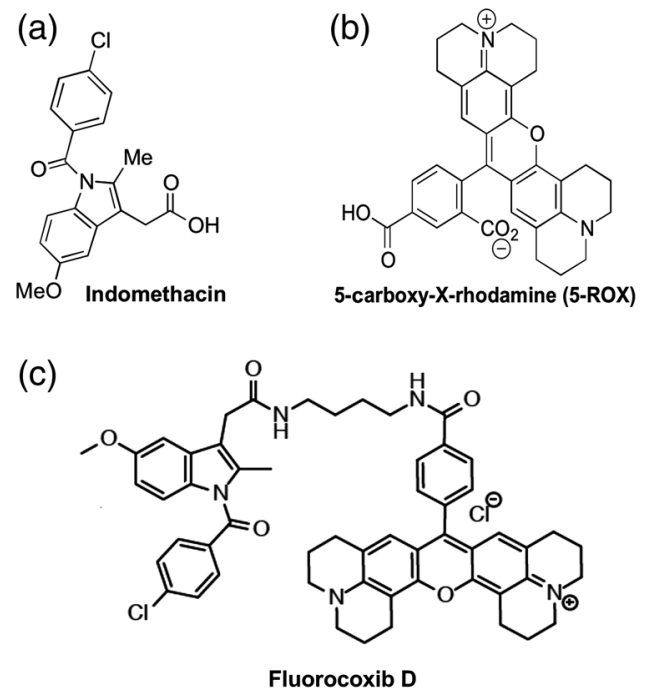

Fig. 1 Chemical structure of (a) indomethacin, (b) 5-carboxy-X-rhodamine (5-ROX), and (c) fluorocoxib D.

Table 1 Indomethacin, fluorocoxib A, and fluorocoxib D inhibit COX-1 and COX-2 activities.

\begin{tabular}{|c|c|c|c|c|}
\hline & \multicolumn{4}{|c|}{$\mathrm{IC}_{50}(\mu \mathrm{M})$} \\
\hline & COX1 & cox2 & Ratio (COX1/COX2) & RAW264.7 macrophages \\
\hline Indomethacin ${ }^{47}$ & $0.19 \pm 0.13$ & $20.9 \pm 10.4$ & 0.009 & $0.01^{29}$ \\
\hline Fluorocoxib $A^{29}$ & 25 & 0.7 & 35.7 & 0.31 \\
\hline Fluorocoxib $D^{39}$ & 4 & 0.23 & 17.4 & - \\
\hline
\end{tabular}

supplemented with $10 \%$ fetal bovine serum, 100 I.U. penicillin, and $100 \mu \mathrm{g} / \mathrm{ml}$ streptomycin (complete media) and grown in an atmosphere of $5 \% \mathrm{CO}_{2}$ at $37^{\circ} \mathrm{C}$.

\subsection{Fluorocoxib D Uptake by Human 5637 Cancer Cells}

Human 5637 cells were seeded on four-chamber slides (Nalge Nunc, Rochester, New York) and grown until reached $70 \%$ to $80 \%$ confluence. Then, the cells were pretreated with or without $10 \mu \mathrm{M}$ celecoxib for $30 \mathrm{~min}$ followed by a treatment with $50 \mathrm{nM}$ fluorocoxib D for an additional $30 \mathrm{~min}$. After this treatment, cells were washed with PBS and incubated for additional $1 \mathrm{~h}$ in complete media to remove any unbound fluorocoxib D. Cells were then washed twice with PBS and fixed in $10 \%$ formalin for $15 \mathrm{~min}$ at room temperature. The nuclei of cells were stained with DAPI for $10 \mathrm{~min}$, and slides were mounted using an aqueous mounting medium. Images of cells were captured by a Leica DMi8 fluorescent microscope with Hamamatsu Orca Flash 4.0LT Digital CMOS Camera (Leica Microsystems Inc., Chicago, Illinois) using Leica Application Suite X software (LASX, Leica).

\subsection{Research Healthy Dogs}

The animal studies were performed in the accordance with the University of Tennessee Institutional Animal Care and Use Committee (UT IACUC)-approved protocols and in an accordance with NIH guidelines. Individually housed research healthy female beagle dogs (Covance Research Product) with weights of 6.7 to $10.3 \mathrm{~kg}$ were used to assess the safety and pharmacokinetic parameters of fluorocoxib D administrated a dose of $1 \mathrm{mg} / \mathrm{kg}$ over $20 \mathrm{~min}$ intravenously (i.v.). 


\subsection{Pilot Safety Study of Fluorocoxib D in Research Dogs}

For single dose safety evaluation studies, we administrated fluorocoxib D at $1 \mathrm{mg} / \mathrm{kg}$, i.v. using a preplaced cephalic or saphenous vein catheter over $20 \mathrm{~min}$ to six healthy research dogs following protocol as described previously. ${ }^{38}$ Briefly, physical examinations for signs of potential drug toxicity were performed before, during, and daily for 3 days after fluorocoxib D administration. Physical assessment included auscultation of heart and lungs, abdominal palpation, body temperature, appetite, attitude, activity levels monitoring, and other health-related events. Hypersensitivity was evaluated by direct observation of each dog during treatment for clinical signs of an allergic reaction (facial swelling, flushing, urticaria, dyspnea, scratching, and changes of heart rates). Signs of adverse events after fluorocoxib D administration were monitored daily, including vomiting, diarrhea, depression, nausea, and increased salivation. Laboratory evaluations of blood and urine were carried out before and 3 days after fluorocoxib $\mathrm{D}$ administration to monitor signs of toxicity. Blood (up to $3 \mathrm{ml}$ ) was collected into ethylenediaminetetraacetic acid (EDTA) and heparin-treated tubes, and urine (up to $5 \mathrm{ml}$ ) was collected by cystocentesis or from the floor of the runs. The laboratory evaluation consisted of a complete blood count (CBC), serum chemistry profile, and complete urinalysis. The CBC evaluated total white blood cells (WBC) and hematocrit (HCT), in addition to absolute numbers of neutrophils, lymphocytes, monocytes, eosinophils, and platelets. The plasma chemistry profile evaluated blood urea nitrogen (BUN), creatinine, proteins (albumin, globulins, and total proteins), alanine aminotransferase (ALT), total bilirubin, glucose, and electrolytes. The complete urinalysis evaluated urine proteins, glucose, and ketones; a sediment examination and urine-specific gravity were validated as well for any possible signs of renal toxicity of fluorocoxib D. All laboratory tests were carried out at the Veterinary Medical Center of the University of Tennessee in Knoxville.

\subsection{Pharmacokinetics of Fluorocoxib $D$ in Research Dogs}

To determine the pharmacokinetic parameters of fluorocoxib $\mathrm{D}(1 \mathrm{mg} / \mathrm{kg}$, i.v.) in dogs, blood (2 to $3 \mathrm{ml}$ ) was collected from the jugular vein into EDTA-treated tubes at $0,0.5,1,2,4,8$, and $24 \mathrm{~h}$ after compound administration. The blood was centrifuged within 20 min of sample collection. Plasma was removed and stored at $-80^{\circ} \mathrm{C}$ until further HPLC analysis.

\subsection{HPLC Analysis of Plasma}

Levels of fluorocoxib D were determined in collected canine plasma samples using HPLC at Vanderbilt University (JU). The frozen samples were thawed and extracted with acetonitrile. The organic layer was collected, dried, and reconstituted in methanol and water. The unknown samples were quantitated against a 5-point standard curve, which was prepared by mixing known quantities of fluorocoxib D with commercial canine plasma (Sigma-Aldrich) and subjecting the resulting samples to liquid-liquid extraction and HPLC. Samples were analyzed using a reversephase column $(\mathrm{C} 18,5 \times 0.2 \mathrm{~cm}$, Phenomenex $)$ with gradient elution. The mobile phase component $\mathrm{A}$ was water, and $\mathrm{B}$ was acetonitrile, each containing $0.1 \%$ acetic acid. The gradient was $50 \%$ B to $90 \%$ B over $5 \mathrm{~min}$, followed by a brief hold and return to initial conditions. The flow rate was $0.3 \mathrm{ml} / \mathrm{min}$.

\subsection{Pharmacokinetic Parameters}

The pharmacokinetic parameters for fluorocoxib D were estimated from the plasma concentration-time data by a nonlinear mixed effects approach, as implemented with Monolix 4.1.2 (Lixoft S.A.S., Orsay, France). This approach allowed analyzing data from all animals at the same time and was ideal for relatively sparse datasets like the one used in this study. The plasma clearance $(\mathrm{Cl})$, representing the overall ability of the body to eliminate fluorocoxib $\mathrm{D}$, was determined by scaling its elimination rate (amount per time) by the corresponding plasma concentration level. The volume of distribution (Vd) was defined as the ratio of the total amount of fluorocoxib $\mathrm{D}$ in the body to the blood plasma concentration. The $\mathrm{Cl}$ and $\mathrm{Vd}$ were estimated directly from the study population data. The peak concentration in plasma $\left(C_{\max }\right)$ and the 
following pharmacokinetic parameters were obtained by averaging the corresponding post-hoc Bayesian estimates. The individual partial areas under the curve between times 0 and $8 \mathrm{~h}$ $\left(\mathrm{AUC}_{0-8}\right)$ and the $\mathrm{AUC}_{0-\infty}$ with extrapolation to infinity were calculated using the log-linear trapezoidal rule, as implemented with WinNonlin 5.1 (Pharsight, Mountain View, California). The mean residence time (MRT) value was determined as the ratio of the area under the first moment curve over $\mathrm{AUC}_{0-\infty}$. The elimination rate constant was determined as the slope obtained by linear regression of the terminal log-linear portion of the concentration versus time curve, and the elimination half-life $\left(t_{1 / 2}\right)$ was then calculated. The plasma concentration graphs were generated using calculated averaged plasma concentrations of fluorocoxib $\mathrm{D}$ from six dogs after $1 \mathrm{mg} / \mathrm{kg}$ i.v. of fluorocoxib D administration performed over $20 \mathrm{~min}$.

\subsection{Rhinoscopy-Guided Biopsy Sample Collection from a Client-Owned Dog with HNC Mass}

A client-owned dog diagnosed with naturally occurring cancer was enrolled in our study through the Veterinary Medical Center by the Internal Medicine Service to validate the selective uptake of fluorocoxib D in cancer cells. The owners signed a consent form for enrolling their dog for our proof-of principal study. A nine-year old female-spayed Golden Retriever dog weighing $35 \mathrm{~kg}$ was presented for an acute onset of unilateral right-sided epistaxis of 5-day duration. Previous medical history included a grade 2 soft tissue sarcoma with a high mitotic index that was completely excised from her ventral neck $\sim 2$ years prior with no signs of regrowth. Rhinoscopy and biopsy procedure in the dog was performed by board-certified veterinary internal specialists (SO and JS) in an accordance with a standard veterinary care and the UT IACUC-approved protocol. Fluorocoxib D was administrated i.v. $1 \mathrm{mg} / \mathrm{kg}$ over $20 \mathrm{~min}$ using a catheter, followed by a half hour uptake before initiation of rhinoscopy procedure. Rhinoscopy was used to obtain biopsy samples guided by uptaken fluorocoxib D in the computed tomography (CT)-identified head and neck cancer (HNC) mass. Rhinoscopy and biopsy procedures in dog were performed under general anesthesia using a $2.7-\mathrm{mm}, 30-\mathrm{deg}, 18-\mathrm{cm}$ rigid scope (Karl Storz Veterinary Endoscopy) attached to a TRICAM PDD as described previously ${ }^{38}$ using a custom-designed filter system for detection of fluorocoxib $\mathrm{D}\left(\lambda_{\mathrm{em}} 645 \pm 50 \mathrm{~nm}\right)$. After complete recovery from the rhinoscopic examination and anesthesia in a quiet room, the client-owned dog was returned to its owners. The heat map images with adjusted hue saturation of fluorocoxib D signal (pink color) from normal tissue (upper three images) and $\mathrm{HNC}$ tumor (lower three images) obtained during rhinoscopy were generated using Adobe Photoshop CC2019 software (Adobe Acrobat) in order to better visualize the tumor and its margins. Tumor-to-normal tissue ratio (T/N ratio) of fluorocoxib $\mathrm{D}$ signal obtained from normal $(n=804)$ and tumor regions of interest (ROI) $(n=866)$ from plot profile images generated from ImageJ software (NIH).

\subsection{Computed Tomography in a Client-Owned Dog with HNC Mass}

CT of head in the client-owned dog was performed using a multislice helical CT scanner (Philips Brilliance-40, Philips International B.V., Amsterdam, Netherlands). A submillimeter multislice dataset of the head was acquired, and images were reconstructed in 0.9- and 4-mm slice thickness utilizing bone and soft tissue algorithms. The acquisition was repeated following intravenous administration of nonionic iodinated contrast medium (Ioversol $350 \mathrm{mg} / \mathrm{ml}, 2.2 \mathrm{mg} / \mathrm{kg}$ [1 mg/lb], Optiray ${ }^{\circledR} 350 \mathrm{mg} / \mathrm{ml}$, Tyco Healthcare/Mallinckrodt, Milwaukee, Wisconsin, USA). Images were evaluated by a board-certified veterinary radiologist $(\mathrm{SH})$.

\subsection{Immunohistochemistry}

The biopsy samples obtained during rhinoscopy procedures in dogs were formalin-fixed and paraffin-embedded and sectioned at $7-\mu \mathrm{m}$ thin sections for histology and immunohistochemistry analysis for detection of COX-2 and Ki67 expression as described previously. ${ }^{38}$ For the antigen retrieval, sodium citrate buffer (10 mM, pH 6.0) was used for unmasking COX-2 and Ki67 proteins. Endogenous peroxidase activity was blocked by $3 \%$ hydrogen peroxide, and nonspecific binding of secondary antibody was eliminated by incubation with protein block buffer 
(Biogenex USA, San Ramon, California) for $30 \mathrm{~min}$ at room temperature. Slides were incubated with primary antibodies for COX-2 (1:500) or Ki67 (1:500) overnight at $4^{\circ} \mathrm{C}$, followed by incubation with specific secondary antibodies, streptavidin/biotin horseradish peroxidase complex (Biogenex), and visualized by DAB staining. Sections were lightly stained with Mayer's hematoxylin. The tissue specimens were evaluated using a Leitz DMRB microscope. The images were captured by a DP73 camera attached to microscope using CellSens Standard software (Olympus, Pittsburgh, Pennsylvania).

\section{Results}

\subsection{Safety of Administration of Fluorocoxib $D$ to Research Dogs}

To assess the safety of a single dose of fluorocoxib $\mathrm{D}$, six female healthy research dogs were administered with fluorocoxib D (1 mg/kg, i.v., over $20 \mathrm{~min})$. A physical examination, CBC (Table 2), serum chemistry profile (Table 3 ), and complete urinalysis (Table 4) confirmed the

Table 2 CBC analysis of blood before and 3 days after a single dose of fluorocoxib D (1 mg/kg, i.v.) in six healthy research dogs.

\begin{tabular}{|c|c|c|c|c|c|c|c|c|c|}
\hline Test analysis & & $\begin{array}{c}\text { Dog } \\
\# 1\end{array}$ & $\begin{array}{c}\text { Dog } \\
\# 2\end{array}$ & $\begin{array}{c}\text { Dog } \\
\# 3\end{array}$ & $\begin{array}{c}\text { Dog } \\
\# 4\end{array}$ & $\begin{array}{c}\text { Dog } \\
\# 5\end{array}$ & $\begin{array}{c}\text { Dog } \\
\# 6\end{array}$ & $\begin{array}{c}\text { Reference } \\
\text { ranges at } \\
\text { UTCVM }\end{array}$ & Units \\
\hline \multirow[t]{2}{*}{ WBC } & Before & 6.9 & 7.4 & 7 & 6.8 & 6.5 & 6 & \multirow{2}{*}{5.1 to 14} & \multirow{2}{*}{$\times 10^{3} / \mu \mathrm{l}$} \\
\hline & After & 5.3 & 5.7 & 6.6 & 7.3 & 7.8 & 5.3 & & \\
\hline \multirow[t]{2}{*}{ HCT } & Before & 45.1 & 50.1 & 44.7 & 46.4 & 51.5 & 45.4 & \multirow{2}{*}{41 to 60} & \multirow{2}{*}{$\%$} \\
\hline & After & 45.2 & 47.2 & 45.6 & 47.2 & 47 & 48.1 & & \\
\hline \multirow[t]{2}{*}{ Abs SEG } & Before & 4.11 & 4.42 & 4.78 & 4.49 & 3.72 & 3.94 & \multirow{2}{*}{2.65 to 9.8} & \multirow{2}{*}{$\times 10^{3} / \mu \mathrm{l}$} \\
\hline & After & 3.22 & 2.98 & 4 & 4.72 & 5.07 & $2.4 L$ & & \\
\hline \multirow[t]{2}{*}{ Abs BAN } & Before & $\mathrm{N} / \mathrm{A}$ & $\mathrm{N} / \mathrm{A}$ & $\mathrm{N} / \mathrm{A}$ & $\mathrm{N} / \mathrm{A}$ & $\mathrm{N} / \mathrm{A}$ & $\mathrm{N} / \mathrm{A}$ & \multirow{2}{*}{0 to 0.3} & \multirow{2}{*}{$\times 10^{3} / \mu \mathrm{l}$} \\
\hline & After & $\mathrm{N} / \mathrm{A}$ & $\mathrm{N} / \mathrm{A}$ & $\mathrm{N} / \mathrm{A}$ & $\mathrm{N} / \mathrm{A}$ & $\mathrm{N} / \mathrm{A}$ & 0 & & \\
\hline \multirow[t]{2}{*}{ Abs LYM } & Before & 2.15 & 2.25 & 1.75 & 1.76 & 3.72 & 1.75 & \multirow{2}{*}{1.1 to 4.6} & \multirow{2}{*}{$\times 10^{3} / \mu \mathrm{l}$} \\
\hline & After & 1.61 & 2.05 & 2.22 & 1.88 & 5.07 & 2.3 & & \\
\hline \multirow[t]{2}{*}{ Abs MON } & Before & 0.28 & 0.31 & 0.31 & 0.38 & 0.26 & 0.22 & \multirow{2}{*}{0.165 to 0.85} & \multirow{2}{*}{$\times 10^{3} / \mu \mathrm{l}$} \\
\hline & After & 0.23 & 0.3 & 0.24 & 0.49 & 0.38 & 0.62 & & \\
\hline \multirow[t]{2}{*}{ Abs EOS } & Before & 0.34 & 0.4 & 0.15 & 0.16 & 0.31 & 0.08 & \multirow{2}{*}{0 to 0.85} & \multirow{2}{*}{$\times 10^{3} / \mu \mathrm{l}$} \\
\hline & After & 0.24 & 0.36 & 0.14 & 0.2 & 0.18 & 0.17 & & \\
\hline \multirow[t]{2}{*}{ PLT EST } & Before & N.D. & $\mathrm{ADQ}$ & N.D. & N.D. & $A D Q$ & $A D Q$ & \multirow{2}{*}{$\mathrm{ADQ}$} & \multirow{2}{*}{ - } \\
\hline & After & N.D. & N.D. & $A D Q$ & N.D. & N.D. & N.D. & & \\
\hline \multirow[t]{2}{*}{ PLT CNT } & Before & $\mathrm{N} / \mathrm{A}$ & 345 & $\mathrm{~N} / \mathrm{A}$ & $\mathrm{N} / \mathrm{A}$ & 256 & 196 & \multirow[t]{2}{*}{147 to 423} & \multirow[t]{2}{*}{$\times 10^{3} / \mu \mathrm{l}$} \\
\hline & After & $\mathrm{N} / \mathrm{A}$ & $\mathrm{N} / \mathrm{A}$ & 241 & $\mathrm{~N} / \mathrm{A}$ & $\mathrm{N} / \mathrm{A}$ & N/A & & \\
\hline
\end{tabular}

Out of reference range values labeled with $\mathrm{H}$-high or L-low in italic.

WBC, white blood cells; HCT, hematocrit; Abs SEG, absolute segmented neutrophils; Abs BAN, absolute band neutrophils; Abs LYM, absolute lymphocytes; Abs MON, absolute monocytes; Abs EOS, absolute eosinophils; PLT EST, platelet estimate; PLT CNT, platelets counts; ADQ, adequate-visual examinations of the blood smears identified an adequate number of platelets; N.D, not determined, samples is clumped and platelet numbers not determine, but ADQ., N/A, not available. 
Table 3 Chemistry panel of serum before and 3 days after a single dose of fluorocoxib $\mathrm{D}$ (i.v., $1 \mathrm{mg} / \mathrm{kg}$ ) in 6 healthy research dogs.

\begin{tabular}{|c|c|c|c|c|c|c|c|c|c|}
\hline Test analysis & & $\begin{array}{c}\text { Dog } \\
\# 1\end{array}$ & $\begin{array}{l}\text { Dog } \\
\# 2\end{array}$ & $\begin{array}{l}\text { Dog } \\
\# 3\end{array}$ & $\begin{array}{c}\text { Dog } \\
\# 4\end{array}$ & $\begin{array}{l}\text { Dog } \\
\# 5\end{array}$ & $\begin{array}{c}\text { Dog } \\
\# 6\end{array}$ & $\begin{array}{l}\text { Reference } \\
\text { ranges at } \\
\text { UTCVM }\end{array}$ & Units \\
\hline \multirow[t]{2}{*}{ BUN } & Before & 11 & 15 & 17 & 13 & 15 & 16 & \multirow{2}{*}{7 to 37} & \multirow{2}{*}{$\mathrm{mg} / \mathrm{dL}$} \\
\hline & After & 12 & 17 & 14 & 16 & 17 & 19 & & \\
\hline \multirow[t]{2}{*}{ CREATI } & Before & 0.7 & 0.6 & 0.7 & 0.6 & 0.9 & 0.6 & \multirow{2}{*}{0.3 to 1.1} & \multirow{2}{*}{$\mathrm{mg} / \mathrm{dL}$} \\
\hline & After & 0.8 & 0.6 & 0.8 & 0.6 & 0.8 & 0.6 & & \\
\hline \multirow[t]{2}{*}{ TOT. PROT } & Before & 5.4 & 5.8 & 5.8 & 5.7 & 5.7 & $5.2 L$ & \multirow{2}{*}{5.4 to 6.8} & \multirow{2}{*}{$\mathrm{g} / \mathrm{dL}$} \\
\hline & After & 5.4 & 5.4 & 5.7 & 5.6 & 5.6 & $5.2 L$ & & \\
\hline \multirow[t]{2}{*}{ ALBUM } & Before & $3 L$ & 3.6 & 3.4 & 3.3 & 3.8 & 3.3 & \multirow{2}{*}{3.2 to 4.3} & \multirow{2}{*}{$\mathrm{g} / \mathrm{dL}$} \\
\hline & After & $3.1 L$ & 3.4 & 3.4 & $3 L$ & 3.5 & 3.3 & & \\
\hline \multirow[t]{2}{*}{ GLOB } & Before & 2.4 & 2.2 & 2.4 & 2.4 & 1.9 & 1.9 & \multirow{2}{*}{1.9 to 3.1} & \multirow{2}{*}{$\mathrm{g} / \mathrm{dL}$} \\
\hline & After & 2.3 & 2 & 2.3 & 2.6 & 2.1 & 2 & & \\
\hline \multirow[t]{2}{*}{ GLUCO } & Before & 101 & 101 & 91 & 87 & 105 & 103 & \multirow{2}{*}{82 to 132} & \multirow{2}{*}{$\mathrm{mg} / \mathrm{dL}$} \\
\hline & After & 94 & 103 & 100 & 91 & 105 & 110 & & \\
\hline \multirow[t]{2}{*}{ CAL } & Before & $9.2 L$ & 10.5 & $9.9 L$ & $9.8 L$ & 10.4 & $9.3 L$ & \multirow{2}{*}{10 to 12} & \multirow{2}{*}{$\mathrm{mg} / \mathrm{dL}$} \\
\hline & After & $9.5 L$ & 10 & $9.9 L$ & $9.7 L$ & 10.3 & $9.4 L$ & & \\
\hline \multirow[t]{2}{*}{ PHOS } & Before & 3.3 & 4.3 & 3.6 & 2.6 & 3.3 & 2.7 & \multirow[b]{2}{*}{2.5 to 5.9} & \multirow[b]{2}{*}{$\mathrm{mg} / \mathrm{dL}$} \\
\hline & After & 3.5 & 4.3 & 3.3 & 3.9 & 3.4 & 3.6 & & \\
\hline \multirow[t]{2}{*}{ ALT } & Before & 25 & 24 & 22 & 22 & 22 & 21 & \multirow[b]{2}{*}{18 to 100} & \multirow[b]{2}{*}{$\mathrm{U} / \mathrm{L}$} \\
\hline & After & 26 & 23 & 26 & 22 & 22 & 25 & & \\
\hline \multirow[t]{2}{*}{ SOD } & Before & 145 & 146 & 146 & 146 & $148 H$ & 147 & \multirow{2}{*}{141 to 147} & \multirow{2}{*}{$\mathrm{mEq} / \mathrm{L}$} \\
\hline & After & 144 & 146 & 147 & 146 & 147 & $148 H$ & & \\
\hline POTAS & Before & 4.1 & 4.1 & 3.9 & 3.5 & 3.5 & 3.3 & & \\
\hline & After & 3.9 & 4.2 & 3.7 & 3.5 & 3.8 & 3.7 & 2.8 to 4.7 & $\mathrm{mEq} / \mathrm{L}$ \\
\hline CHLOR & Before & 115 & $111 L$ & 113 & $110 L$ & $111 L$ & 115 & & \\
\hline & After & $111 L$ & 114 & 114 & 113 & 112 & 116 & 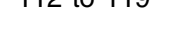 & IILG/L \\
\hline MAG & Before & $0 / 7$ & 0.8 & 0.8 & 0.7 & 0.8 & 0.7 & & \\
\hline & After & 0.7 & 0.8 & 0.8 & 0.7 & 0.7 & 0.7 & 0.65 to 0.98 & $\mathrm{mmol} / \mathrm{L}$ \\
\hline TOT BILI & Before & N/A & 0.1 & 0.1 & 0.1 & 0.1 & $\mathrm{~N} / \mathrm{A}$ & & \\
\hline & After & 0.1 & N/A & 0.1 & $\mathrm{~N} / \mathrm{A}$ & $\mathrm{N} / \mathrm{A}$ & 0.1 & 0.1 to 0.6 & $\mathrm{mg} / \mathrm{dL}$ \\
\hline
\end{tabular}

Out of reference range values labeled with $\mathrm{H}$-high or L-low in italic.

BUN, blood urea nitrogen; CREATI, creatinine; TOT PROT, total proteins; ALBUM, albumin; GLOB, globulin; GLUCO, glucose; CAL, calcium; PHOS, phosphorus; ALT, alanine aminotransferase; SOD, sodium; POTAS, potassium; CHLOR, chlorine; MAG, magnesium; TOT BILI, total bilirubin; N/A, not available. 
Table 4 Analysis of urine samples before and 3 days after a single dose of fluorocoxib $D(1 \mathrm{mg} / \mathrm{kg}$, i.v.) in six healthy research dogs.

\begin{tabular}{|c|c|c|c|c|c|c|c|c|c|}
\hline Test analysis & & $\begin{array}{c}\text { Dog } \\
\# 1\end{array}$ & $\begin{array}{l}\text { Dog } \\
\# 2\end{array}$ & $\begin{array}{c}\text { Dog } \\
\# 3\end{array}$ & $\begin{array}{c}\text { Dog } \\
\# 4\end{array}$ & $\begin{array}{l}\text { Dog } \\
\# 5\end{array}$ & $\begin{array}{c}\text { Dog } \\
\# 6\end{array}$ & $\begin{array}{c}\text { Reference } \\
\text { ranges at } \\
\text { UTCVM }\end{array}$ & Units \\
\hline \multirow[t]{2}{*}{ SP. GRAV } & Before & 1.022 & 1.023 & 1.05 & 1.025 & 1.026 & 1.027 & \multirow{2}{*}{-} & \multirow{2}{*}{-} \\
\hline & After & 1.03 & 1.039 & 1.032 & 1.039 & N/A & 1.044 & & \\
\hline \multirow[t]{2}{*}{$\mathrm{PH}$} & Before & 5.5 & 8.5 & 7.5 & 8.5 & 6.5 & 7 & \multirow{2}{*}{5 to 9} & \multirow{2}{*}{-} \\
\hline & After & $>9 H$ & 6 & 6 & 6 & $\mathrm{~N} / \mathrm{A}$ & 5.5 & & \\
\hline \multirow[t]{2}{*}{ PRO-TEIN } & Before & NEG & NEG & $2+$ & $1+$ & NEG & NEG & \multirow{2}{*}{ NEG-1+ } & \multirow{2}{*}{-} \\
\hline & After & $2+$ & NEG & NEG & NEG & N/A & TRACE & & \\
\hline \multirow[t]{2}{*}{ KETO-NES } & Before & NEG & TRACE & $1+$ & $1+$ & NEG & $1+$ & \multirow{2}{*}{ NEG } & \multirow{2}{*}{-} \\
\hline & After & NEG & NEG & TRACE & TRACE & $\mathrm{N} / \mathrm{A}$ & NEG & & \\
\hline \multirow[t]{2}{*}{ GLU-COSE } & Before & NEG & NEG & NEG & NEG & NEG & NEG & \multirow{2}{*}{ NEG } & \multirow{2}{*}{$\mathrm{mg} / \mathrm{dL}$} \\
\hline & After & NEG & NEG & NEG & NEG & $\mathrm{N} / \mathrm{A}$ & NEG & & \\
\hline \multirow[t]{2}{*}{$\mathrm{BLD} / \mathrm{Hb}$} & Before & NEG & NEG & NEG & NEG & NEG & NEG & \multirow{2}{*}{$N E G$} & \multirow{2}{*}{ - } \\
\hline & After & NEG & TRACE & TRACE & $1+$ & $\mathrm{N} / \mathrm{A}$ & NEG & & \\
\hline \multirow[t]{2}{*}{ WBC/HPF } & Before & $\mathrm{N} / \mathrm{A}$ & N/A & $\mathrm{N} / \mathrm{A}$ & 0 to 1 & $\mathrm{~N} / \mathrm{A}$ & N/A & \multirow{2}{*}{0 to 5} & \multirow{2}{*}{ \#/HPF } \\
\hline & After & 0 to 2 & 0 to 1 & 0 to 1 & 0 to 2 & $\mathrm{~N} / \mathrm{A}$ & 0 to 3 & & \\
\hline \multirow[t]{2}{*}{ RBC/HPF } & Before & $\mathrm{N} / \mathrm{A}$ & N/A & N/A & 5 to 10 & $\mathrm{~N} / \mathrm{A}$ & $\mathrm{N} / \mathrm{A}$ & \multirow[b]{2}{*}{0 to 5} & \multirow[b]{2}{*}{ \#/HPF } \\
\hline & After & 0 to 2 & 12 to $15 \mathrm{H}$ & 10 to $19 \mathrm{H}$ & 5 to 10 & N/A & 0 to 3 & & \\
\hline \multirow[t]{2}{*}{ CASTS } & Before & $\mathrm{N} / \mathrm{A}$ & N/A & N/A & $\mathrm{N} / \mathrm{A}$ & N/A & N/A & \multirow{2}{*}{0} & \multirow{2}{*}{ \#/LPF } \\
\hline & After & N/A & N/A & N/A & N/A & N/A & N/A & & \\
\hline
\end{tabular}

Out of reference range values labeled with $\mathrm{H}$-high or $\mathrm{L}$-low in italic.

SP. GRAV, urine-specific gravity; $\mathrm{PH}, \mathrm{pH} ; \mathrm{BLD} / \mathrm{Hb}$, blood/hemoglobin; WBC/HPF, white blood cells per high power field; RBC/HPF, red blood cells per high power field; LPF, low power field; N/A, not available

clinically healthy status of the research dogs at baseline and 3 days after administration of fluorocoxib D. Of note, there were a few parameters that were outside of the normal laboratory reference ranges. Four dogs (dog \#1, \#3, \#4, and \#6) had low normal or mild hypoalbuminemia before and after administration of fluorocoxib D; the hypoalbuminemia remained stable in these dogs before and after fluorocoxib D administration (Table 3). One dog (dog \#6) developed mild neutropenia 3 days after fluorocoxib $\mathrm{D}$ administration but remained afebrile and clinically normal; the cause of neutropenia in this dog was uncertain. The finding of hypoalbuminemia and mild hypocalcemia may reflect a chronic subclinical condition in these dogs. The mild hypernatremia (dog \#6, Table 3) likely reflects subclinical dehydration given the well-concentrated urine (urine specific gravity 1.044, Table 4). The trace protein on urine dipstick is likely because the urine is well-concentrated. Three days after fluorocoxib D administration, two dogs (dogs \#4 and \#6) had bacteriuria (Table 4). Given the absence of pyuria, the bacteriuria could be iatrogenic or represent asymptomatic bacteriuria. The finding of bacteriuria is not thought to be relevant to this acute toxicity study. Adverse events including diarrhea, vomiting, nausea, and loss of appetite were not observed, although one dog exhibited increased salivation during the administration of fluorocoxib D over $20 \mathrm{~min}$, most likely due to irritation from present DMSO as a one of the 


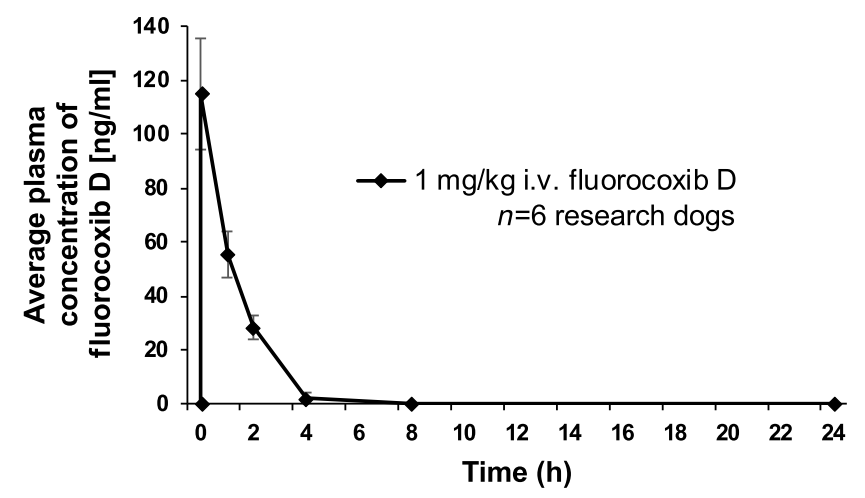

Fig. 2 The time course of fluorocoxib $\mathrm{D}$ plasma concentrations over $24 \mathrm{~h}$ of fluorocoxib $\mathrm{D}$ following administration by HPLC analysis. The data represent the mean plasma concentrations of fluorocoxib $\mathrm{D}(\mathrm{ng} / \mathrm{ml})$ at specific time points following $1 \mathrm{mg} / \mathrm{kg}$ i.v. administration over $20 \mathrm{~min}$ collected from research dogs $(n=6)$ and validated by HPLC analysis.

solvents of fluorocoxib D. Overall, the data indicate that single-dose administration of fluorocoxib D used at the dose of $1 \mathrm{mg} / \mathrm{kg}$ was a safe dose for dogs.

\subsection{Pharmacokinetic Characteristics of Fluorocoxib $D$ in Dogs}

Pharmacokinetic parameters for fluorocoxib D were evaluated following i.v. administration of $1 \mathrm{mg} / \mathrm{kg}$ over $20 \mathrm{~min}$. Peak concentration of fluorocoxib D $(114.8 \pm 50.5 \mathrm{ng} / \mathrm{ml})$ was detected in plasma collected at $0.5 \mathrm{~h}$ after administration using a HPLC analysis as shown in Fig. 2. No fluorocoxib $\mathrm{D}$ was detected in plasma after $4 \mathrm{~h}$ following administration. The calculated pharmacokinetic parameters were shown as mean \pm standard deviations (S.D.) in Table 5.

\subsection{Specific Uptake of Fluorocoxib D in COX-2-Expressing 5637 Cells In Vitro}

To validate the specificity of fluorocoxib D uptake by human 5637 cancer cells, cells were pretreated with or without $10 \mu \mathrm{M}$ celecoxib, a COX-2 selective inhibitor for $30 \mathrm{~min}$, followed by 50-nM fluorocoxib D treatment for additional $30 \mathrm{~min}$. Selective uptake of fluorocoxib D (red color) was detected in COX-2-positive 5637 cancer cells as shown in Fig. 3(a). Celecoxib prevented binding of fluorocoxib D to COX-2 enzyme in 5637 cancer cells as shown in Fig. 3(b). Nuclei of 5637 cells were counterstained with DAPI (blue) staining.

\subsection{Specific Uptake of Fluorocoxib D in COX-2-Expressing Cancer Cells In Vivo in a Dog During Rhinoscopy-Guided Biopsy Procedure}

To validate the specific uptake of fluorocoxib D by COX-2-expressing cancer cells, we used a dog with naturally occurring and CT-identified HNC mass as a model of human cancer. In a dog

Table 5 Pharmacokinetic parameters (mean \pm S.D.) of fluorocoxib $D$ determined after i.v. $1 \mathrm{mg} / \mathrm{kg}$ administration in six research dogs.

\begin{tabular}{lccccccc}
\hline \hline $\begin{array}{l}\text { Pharmacokinetic } \\
\text { parameters }\end{array}$ & $\begin{array}{c}C_{\max } \\
(\mathrm{mg} / \mathrm{L})\end{array}$ & $t_{1 / 2}(\mathrm{~h})$ & $\begin{array}{c}\mathrm{AUC}_{0-\infty} \\
\left(\mathrm{mg}^{*} \mathrm{~h} / \mathrm{L}\right)\end{array}$ & $\begin{array}{c}\mathrm{AUC}_{0-8} \\
\left(\mathrm{mg}^{*} \mathrm{~h} / \mathrm{L}\right)\end{array}$ & $\mathrm{MRT}(\mathrm{h})$ & $\begin{array}{c}\mathrm{Cl} \\
\left(\mathrm{L} / \mathrm{kg}^{*} \mathrm{~h}\right)\end{array}$ & $\begin{array}{c}\mathrm{Vd}_{\text {area }} \\
(\mathrm{L} / \mathrm{kg})\end{array}$ \\
\hline $\begin{array}{l}\text { Fluorocoxib D } \\
(1 \mathrm{mg} / \mathrm{kg}, \mathrm{i} . \mathrm{v} .)\end{array}$ & $0.11 \pm 0.05$ & $0.91 \pm 0.29$ & $0.15 \pm 0.05$ & $0.11 \pm 0.04$ & $1.46 \pm 0.42$ & $7.4 \pm 2.34$ & $9.97 \pm 4.76$ \\
\hline \hline
\end{tabular}

$C_{\max }$, maximum plasma concentration; $t_{1 / 2}$, terminal half-life; $\mathrm{AUC}_{0-\infty}$, area under the plasma concentration time curve from time 0 to infinity; $A \mathrm{CC}_{0-8}$, area under the plasma concentration time curve from time 0 to $8 \mathrm{~h}$; MRT, mean residence time; $\mathrm{Cl}$, clearance; $\mathrm{Vd}_{\mathrm{area}}$, volume of distribution. 

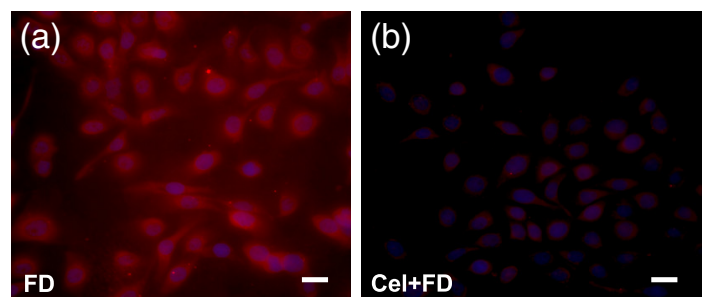

Fig. 3 Specific uptake of fluorocoxib D by human bladder cancer 5637 cells in vitro. (a) 5637 cells were treated with $50 \mathrm{nM}$ fluorocoxib D for $30 \mathrm{~min}$. (b) 5637 cells were pretreated with $10 \mu \mathrm{M}$ celecoxib for $30 \mathrm{~min}$ followed by $50 \mathrm{nM}$ fluorocoxib $\mathrm{D}$ treatment for $30 \mathrm{~min}$. After treatment, cells were washed three times with PBS, incubated for additional $1 \mathrm{~h}$ with fresh complete media, fixed and counterstained with DAPI (blue). 40x objective, scale bar $25 \mu \mathrm{m}$. FD, fluorocoxib D; Cel, Celecoxib.

CT revealed an ill-defined, lobular, mostly soft tissue attenuating, and mildly heterogeneous mass occupying almost the entire mid to caudal right nasal passage and resulting in extensive turbinate destruction as shown in Fig. 4(a). There was also evidence of early lysis and multifocal thinning of the nasal septum. The mass extended from the level of the right maxillary first premolar tooth to the level of the right fourth maxillary premolar tooth and filled the entire right maxillary recess. The mass displayed moderate heterogeneous contrast enhancement, with multiple rounded hypoattenuating regions with rim enhancement. The mass was visualized during rhinoscopy and directed biopsies were collected [Fig. 4(b)]. Specific uptake of fluorocoxib D was detected in HNC during rhinoscopy procedure in a dog as shown in Fig. 4(b) using white (middle panel) and fluorescence light exposures (right panel, red color). Histopathology analysis using H\&E staining confirmed presence of HNC mass as a canine chondrosarcoma [Fig. 4(c), left panel]. The expression of COX-2 protein was confirmed in obtained HNC biopsy samples as shown in Fig. 4(c) (right panel, brown staining). The presence of Ki67-positive cells of HNC supported the evidence of proliferating cancer cells [Fig. 4(c), middle panel, brown staining]. T/ $\mathrm{N}$ ratio of fluorocoxib $\mathrm{D}$ by canine HNC tumor was validated by ImageJ and Adobe PhotoShop CC2019 software as shown in Fig. 5. The representative heat map images of fluorocoxib D signal (pink color) from normal tissue (upper three images) and HNC tumor (lower three images) obtained during rhinoscopy using Adobe Photoshop CC2019 software (Adobe Acrobat) were shown in Fig. 5(a). The representative plot profile images of normal (left panel) and HNC tumor tissues using ImageJ software (NIH) were shown in Fig. 5(b). The averaged T/N ratio of fluorocoxib D signal obtained from normal $(n=804)$ and tumor ROI $(n=866)$ from plot profile images was in an average $3.7 \pm 0.9$ as was shown in Fig. 5(c).

\section{Discussion}

The potential use of NSAID compounds as imaging agents has come under intense investigation. ${ }^{25-30}$ As previously published, several COX-2-targeted optical, SPECT, and PET imaging agents have been synthesized and shown to detect COX-2 expression in culture human tumor cell lines and/or in tumor xenografts in nude mice. ${ }^{26,29}$ Tested concentrations of fluorocoxib D of $1 \mathrm{mg} / \mathrm{kg}$ confirmed a safe administration with no clinically relevant adverse events based on physical examination, as well as whole blood, serum, and urine analysis. This was similar finding as we had with fluorocoxib A. ${ }^{38}$

Once NSAIDs are absorbed in blood stream, they are highly plasma-protein bound (80\% to 97\%) and have a relatively long elimination half-life. ${ }^{48-51}$ Indomethacin (Indocin) bioavailability is $100 \%$ when administrated orally, and $~ 99 \%$ to $97 \%$ of indomethacin is bound to protein in plasma with an approximate $t_{1 / 2}$ of 0.3 to $4.5 \mathrm{~h}$ in various species. ${ }^{52}$ The elimination $t_{1 / 2}$ of fluorocoxib A was $11.0 \pm 2.5 \mathrm{~h}$ after i.v. administration of $1 \mathrm{mg} / \mathrm{kg}$ in healthy research dogs. ${ }^{38}$ This indicates higher stability of fluorocoxib A than indomethacin or robenacoxib $(1.1 \mathrm{~h}$ after oral administration of $2 \mathrm{mg} / \mathrm{kg}){ }^{53}$ In contrast to fluorocoxib A, elimination $t_{1 / 2}$ of fluorocoxib D was $0.91 \pm 0.29 \mathrm{~h}$ after i.v. administration of $1 \mathrm{mg} / \mathrm{kg}$ in dogs. As compared to fluorocoxib A, which has a volume of distribution $18.3 \pm 3.7 \mathrm{ml} / \mathrm{kg}$ and is fast cleared from 

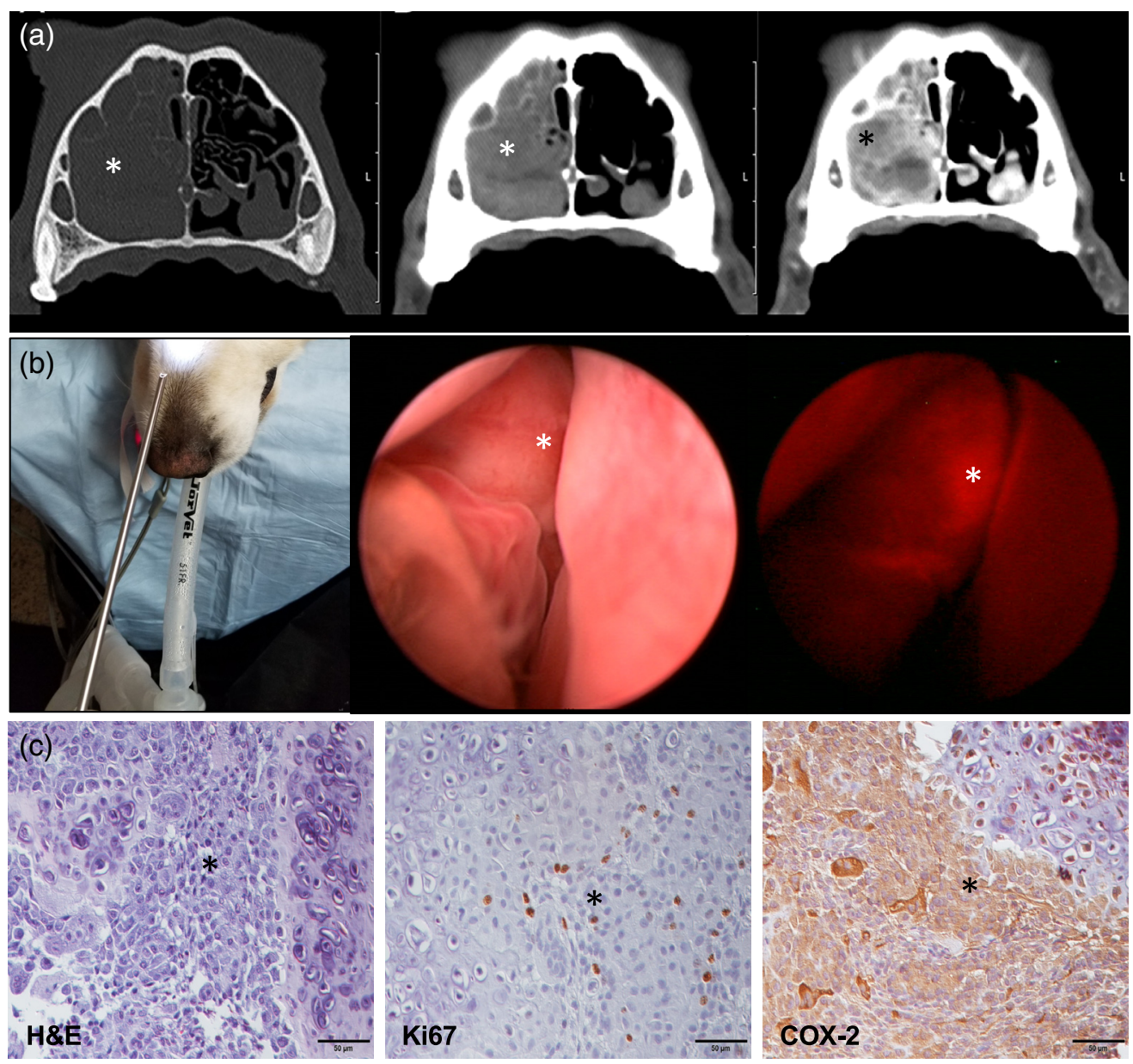

Fig. 4 Fluorocoxib D uptake by canine HNC tumor during rhinoscopy in vivo. (a) Transverse CT images of the nose in a 9-year-old Golden Retriever displayed in a bone window (left panel; window center $600 \mathrm{HU}$, window width $2600 \mathrm{HU}$ ) and in a soft tissue window (window center $50 \mathrm{HU}$, window width $350 \mathrm{HU}$ ) before (middle panel) and after (right panel) intravenous contrast medium administration. HNC mass (asterisk) is associated with and fills nearly the entire right nasal cavity. There is extensive lysis of nasal turbinates and thinning of the nasal septum. On precontrast images, the mass is soft tissue attenuating and mildly heterogeneous (left and middle panels). Following contrast medium administration, there is heterogeneous contrast enhancement with multiple round hypoattenuating regions with rim enhancement, suggesting hemorrhage or necrosis (right panel). (b) Planning of insertion of rigid scope to nasal cavity before rhinoscopy procedure (left panel). A representative image of localized HNC mass (asterisk) by a white light (middle panel) and under fluorescence light (right panel) with specific uptake of fluorocoxib D (red color). (c) A representative histology images of H\&E (left panel), Ki67 (middle panel), and COX-2 (right panel) protein expressions in HNC of chondrosarcoma cells (asterisk) by immunohistochemistry staining (brown color). $20 \times$ objective, scale bar $50 \mu \mathrm{m}$.

blood with a clearance of $0.94 \pm 0.64 \mathrm{~L} / \mathrm{kg} * \mathrm{~h}$ after i.v. administration of $1 \mathrm{mg} / \mathrm{kg},{ }^{38}$ fluorocoxib D has even smaller volume of distribution $9.97 \pm 4.76 \mathrm{ml} / \mathrm{kg}$ and is cleared faster from blood with a clearance of $7.4 \pm 2.34 \mathrm{~L} / \mathrm{kg} * \mathrm{~h}$ as shown in Table 5. No detectable levels of fluorocoxib D were found in any of the tested plasma samples after $4 \mathrm{~h}$, suggesting that fluorocoxib D was degraded and eliminated from the blood at that time point.

HNC are among the most commonly diagnosed cancers in the United States and among the leading causes of cancer death. ${ }^{54,55}$ Early detection and more precise resection during surgery and biopsy procedures are key factors to improve patient's survival rates. Spontaneous cancers in companion dogs offer a unique model for validation of imaging agents and devices for detection of human cancer. The histologic and biologic characteristics of many cancers in dogs are similar 
(a)

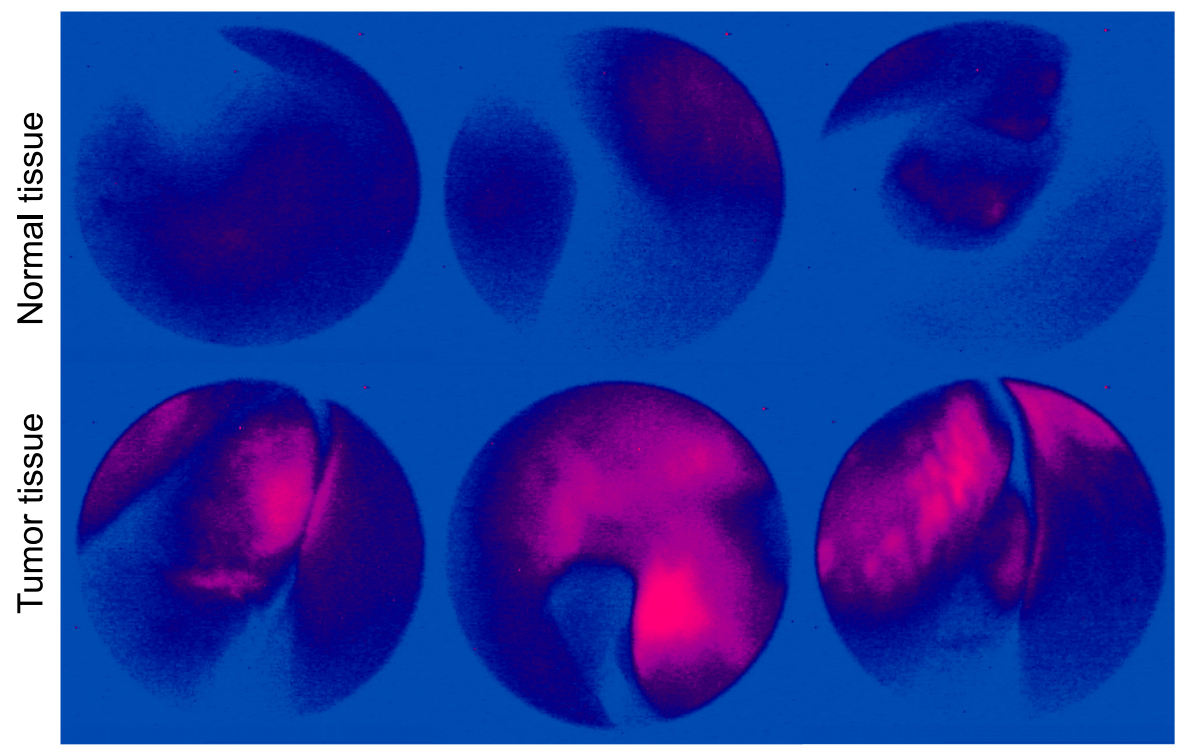

(b)
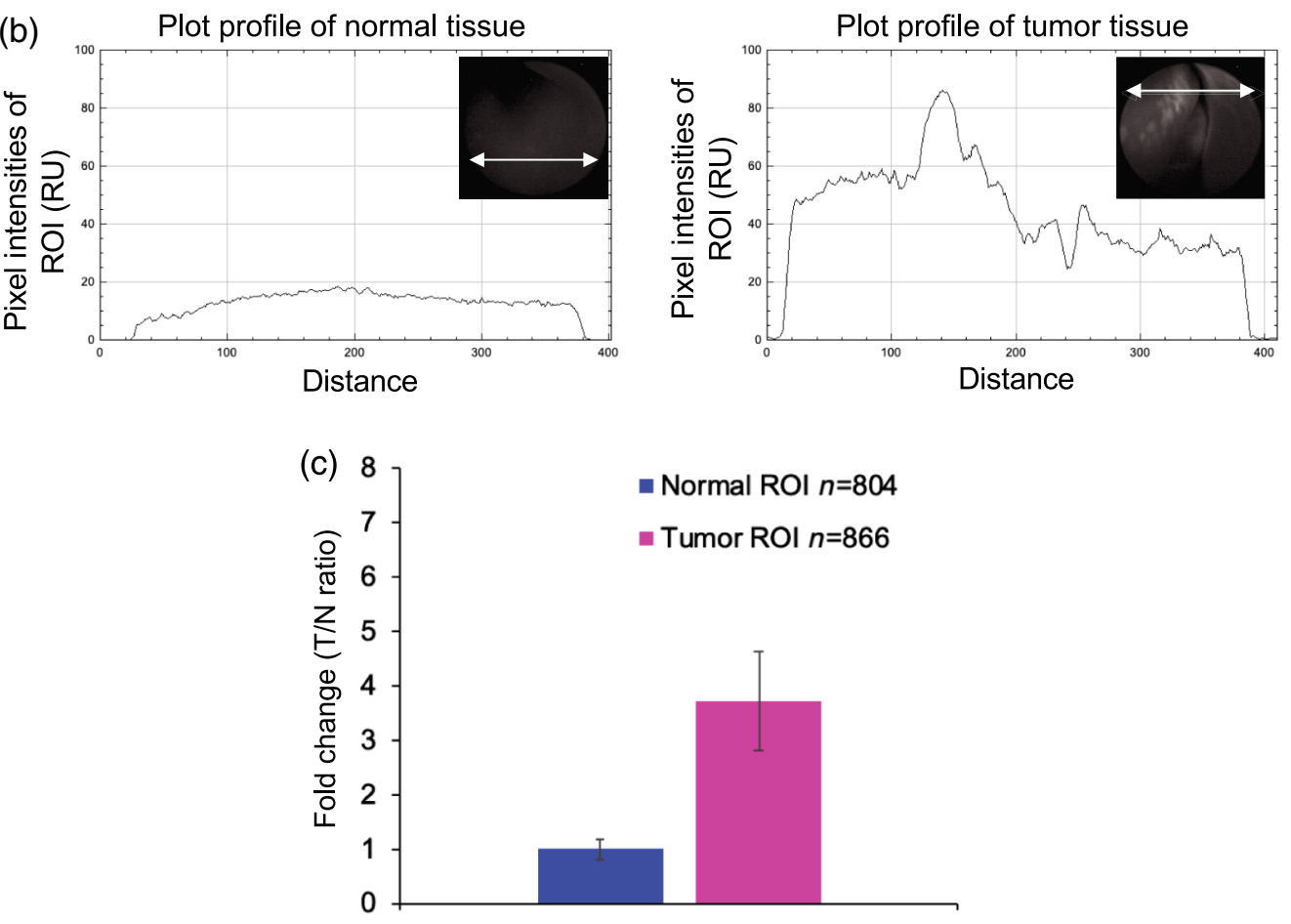

Fig. $5 \mathrm{~T} / \mathrm{N}$ ratio of fluorocoxib $\mathrm{D}$ by canine HNC tumor. (a) Representative heat map images of fluorocoxib D signal (pink color) from normal tissue (upper three images) and HNC tumor (lower three images) obtained during rhinoscopy using Adobe Photoshop CC2019 software (Adobe Acrobat). (b) Representative plot profile images of normal (left panel) and HNC tumor tissues using ImageJ software (NIH). (c) T/N ratio of fluorocoxib D signal obtained from normal $(n=804)$ and tumor ROI $(n=866)$ from plot profile images obtained from ImageJ software.

to those in humans. ${ }^{38,40-46}$ To this end, as a proof-of principal experiment, we evaluated fluorocoxib D, which specifically targets cancer cells using a dog with naturally occurring HNC. As seen in humans, COX-2-positive tumors in $\operatorname{dogs}^{43,46,56-58}$ show strong expression of the protein in the perinuclear area of the cells and in macrophages surrounding the tumors. Specific uptake of fluorocoxib D by COX-2-expressing cells was also confirmed in vitro using human 5637 cancer cells pretreated with celecoxib, the COX-2 selective inhibitor (Fig. 3). Fluorocoxib D specifically bound to COX-2-expressing canine HNC cells and allowed better visualization and 
identification of the COX-2-positive cancers as shown in Fig. 4(b) (right panel, red color). COX-2 expression was confirmed by IHC analysis of biopsy samples as shown in Fig. 4(c) (right panel, brown staining). Specific T/N ratio of detected fluorocoxib D signal was in an average of $3.7 \pm 0.9$ using Image $\mathbf{J}$ analysis as shown in Fig. 5 .

In conclusion, the results reported here demonstrate for the first time the safety and pharmacokinetic parameters of fluorocoxib D in healthy research dogs. In addition, fluorocoxib D uptake by $\mathrm{HNC}$ tumor with an average $3.7 \pm 0.9 \mathrm{~T} / \mathrm{N}$ ratio signal in vivo was confirmed by immunohistochemistry staining for COX-2 expression in obtained HNC tumor biopsy samples. Our data suggest that fluorocoxib D might be a suitable candidate as the optical imaging agent for detection of COX-2-expressing HNC cancer to further assist with an image-guided minimally invasive biopsy procedure.

\section{Disclosures}

Authors from the University of Tennessee have no potential conflicts of interest to disclose. Vanderbilt University holds a patent on fluorocoxibs and their use for COX-2-targeted imaging.

\section{Acknowledgments}

This study was supported by Vanderbilt University (VU) (PI: Cekanova) Grant No. R181721407. We thank Ms. Shanna Hillsman and Gina Galyon for their technical assistance with procedures involving client-owned and research dogs. We thank to VU for supporting the publication charges.

\section{References}

1. B. P. Joshi and T. D. Wang, "Targeted optical imaging agents in cancer: focus on clinical applications," Contrast Media Mol. Imaging 2018, 2015237 (2018).

2. T. Ganguly et al., "Evaluation of two optical probes for imaging the integrin $\alpha_{v} \beta_{6}-$ in vitro and in vivo in tumor-bearing mice," Mol. Imaging Biol. (2020).

3. O. T. Okusanya et al., "Intraoperative molecular imaging can identify lung adenocarcinomas during pulmonary resection," J. Thorac. Cardiovasc. Surg. 150(1), 28-35.e1 (2015).

4. G. M. van Dam et al., "Intraoperative tumor-specific fluorescence imaging in ovarian cancer by folate receptor- $\alpha$ targeting: first in-human results," Nat. Med. 17(10), 1315-1319 (2011).

5. T. J. Guzzo et al., "Intraoperative molecular diagnostic imaging can identify renal cell carcinoma," J. Urol. 195(3), 748-755 (2016).

6. S. Kossatz et al., "Detection and delineation of oral cancer with a PARP1 targeted optical imaging agent," Sci. Rep. 6(1), 21371 (2016).

7. Y. H. W. Derks et al., "PSMA-targeting agents for radio- and fluorescence-guided prostate cancer surgery," Theranostics 9(23), 6824-6839 (2019).

8. V. Perumal et al., "Near infra-red polymeric nanoparticle based optical imaging in cancer diagnosis," J. Photochem. Photobiol. B 199, 111630 (2019).

9. W. L. Smith, D. L. DeWitt, and R. M. Garavito, "Cyclooxygenases: structural, cellular, and molecular biology," Апnи. Rev. Biochem. 69, 145-182 (2000).

10. L. J. Marnett, "The COXIB experience: a look in the rearview mirror," Annu. Rev. Pharmacol. Toxicol. 49, 265-290 (2009).

11. S. I. Abdalla et al., "Gastrin-induced cyclooxygenase-2 expression in Barrett's carcinogenesis," Clin. Cancer Res. 10(14), 4784-4792 (2004).

12. E. G. Cohen et al., "Microsomal prostaglandin E synthase-1 is overexpressed in head and neck squamous cell carcinoma," Clin. Cancer Res. 9(9), 3425-3430 (2003).

13. A. J. Dannenberg and K. Subbaramaiah, "Targeting cyclooxygenase-2 in human neoplasia: rationale and promise," Cancer Cell 4(6), 431-436 (2003).

14. C. E. Eberhart et al., "Up-regulation of cyclooxygenase 2 gene expression in human colorectal adenomas and adenocarcinomas," Gastroenterology 107(4), 1183-1188 (1994). 
15. E. Fosslien, "Molecular pathology of cyclooxygenase-2 in neoplasia," Ann. Clin. Lab. Sci. 30(1), 3-21 (2000).

16. J. S. Goodwin and J. Ceuppens, "Regulation of the immune response by prostaglandins," J. Clin. Immunol. 3(4), 295-315 (1983).

17. H. Inoue et al., "Transcriptional regulation of human prostaglandin-endoperoxide synthase2 gene by lipopolysaccharide and phorbol ester in vascular endothelial cells. Involvement of both nuclear factor for interleukin-6 expression site and cAMP response element," J. Biol. Chem. 270(42), 24965-24971 (1995).

18. H. Sheng et al., "Cyclooxygenase-2 induction and transforming growth factor beta growth inhibition in rat intestinal epithelial cells," Cell Growth Differ 8(4), 463-470 (1997).

19. M. M. Taketo, "COX-2 and colon cancer," Inflamm. Res. 47(Suppl. 2), 112-116 (1998).

20. M. Tsujii et al., "Cyclooxygenase regulates angiogenesis induced by colon cancer cells," Cell 93(5), 705-716 (1998).

21. G. Neufang et al., "Abnormal differentiation of epidermis in transgenic mice constitutively expressing cyclooxygenase-2 in skin," Proc. Natl. Acad. Sci. U. S. A. 98(13), 7629-7634 (2001).

22. C. H. Liu et al., "Overexpression of cyclooxygenase- 2 is sufficient to induce tumorigenesis in transgenic mice," J. Biol. Chem. 276(21), 18563-18569 (2001).

23. M. Oshima et al., "Suppression of intestinal polyposis in Apc delta716 knockout mice by inhibition of cyclooxygenase 2 (COX-2)," Cell 87(5), 803-809 (1996).

24. P. C. Chulada et al., "Genetic disruption of Ptgs-1, as well as Ptgs-2, reduces intestinal tumorigenesis in Min mice," Cancer Res. 60(17), 4705-4708 (2000).

25. Y. Kuge et al., "Synthesis and evaluation of radioiodinated cyclooxygenase-2 inhibitors as potential SPECT tracers for cyclooxygenase-2 expression," Nucl. Med. Biol. 33(1), 21-27 (2006).

26. H. M. Schuller et al., "Detection of overexpressed COX-2 in precancerous lesions of hamster pancreas and lungs by molecular imaging: implications for early diagnosis and prevention," ChemMedChem 1(6), 603-610 (2006).

27. M. J. Uddin et al., "Synthesis and evaluation of [123-I]-indomethacin derivatives as COX-2 targeted imaging agents," J. Labell. Comp. Radiopharmaceut. 52(9), 387-393 (2009).

28. M. J. Uddin et al., "[I]-Celecoxib analogues as SPECT tracers of cyclooxygenase-2 in inflammation," ACS Med. Chem. Lett. 2(2), 160-164 (2011).

29. M. J. Uddin et al., "Selective visualization of cyclooxygenase-2 in inflammation and cancer by targeted fluorescent imaging agents," Cancer Res. 70(9), 3618-3627 (2010).

30. M. J. Uddin and L. J. Marnett, "Synthesis of 5- and 6-carboxy-X-rhodamines," Org. Lett. 10(21), 4799-4801 (2008).

31. J. Bourn et al., "Detection of carcinogen-induced bladder cancer by fluorocoxib A," $B M C$ Cancer 19(1), 1152 (2019).

32. J. Bourn et al., "Detection of tyrosine kinase inhibitors-induced COX-2 expression in bladder cancer by fluorocoxib A," Oncotarget 10(50), 5168-5180 (2019).

33. M. J. Uddin et al., "Fluorocoxib A enables targeted detection of cyclooxygenase-2 in laser-induced choroidal neovascularization," J. Biomed. Opt. 21(9), 090503 (2016).

34. M. J. Uddin et al., "Fluorocoxib A loaded nanoparticles enable targeted visualization of cyclooxygenase-2 in inflammation and cancer," Biomaterials 92, 71-80 (2016).

35. M. J. Uddin et al., "Targeted imaging of cancer by fluorocoxib C, a near-infrared cyclooxygenase-2 probe," J. Biomed. Opt. 20(5), 050502 (2015).

36. H. Ra et al., "Detection of non-melanoma skin cancer by in vivo fluorescence imaging with fluorocoxib A," Neoplasia 17(2), 201-207 (2015).

37. M. J. Uddin et al., "Trifluoromethyl fluorocoxib a detects cyclooxygenase-2 expression in inflammatory tissues and human tumor xenografts," ACS Med. Chem. Lett. 5(4), 446-450 (2014).

38. M. Cekanova et al., "Single-dose safety and pharmacokinetic evaluation of fluorocoxib A: pilot study of novel cyclooxygenase-2-targeted optical imaging agent in a canine model," J. Biomed. Opt. 17(11), 116002 (2012).

39. J. Uddin, "Water-soluble fluorocoxibs in detection of cyclooxygenase-2 in vivo," in Drug Discov. and Ther. World Congr. 2017, p. 103 (2017). 
40. D. W. Knapp and D. J. Waters, "Naturally occurring cancer in pet dogs: important models for developing improved cancer therapy for humans," Mol. Med. Today 3(1), 8-11 (1997).

41. M. Cekanova et al., "Molecular imaging of cyclooxygenase-2 in canine transitional cell carcinomas in vitro and in vivo," Cancer Prevent. Res. 6(5), 466-476 (2013).

42. M. Cekanova and K. Rathore, "Animal models and therapeutic molecular targets of cancer: utility and limitations," Drug Des. Dev. Ther. 8, 1911-1921 (2014).

43. E. P. Spugnini et al., "COX-2 overexpression in canine tumors: potential therapeutic targets in oncology," Histol. Histopathol. 20(4), 1309-1312 (2005).

44. E. G. MacEwen, "Spontaneous tumors in dogs and cats: models for the study of cancer biology and treatment," Cancer Metastasis Rev. 9(2), 125-136 (1990).

45. S. I. Mohammed et al., "Expression of cyclooxygenase-2 (COX-2) in human invasive transitional cell carcinoma (TCC) of the urinary bladder," Cancer Res. 59(22), 5647-5650 (1999).

46. E. M. Pestili de Almeida et al., "Expression of cyclo-oxygenase-2 in naturally occurring squamous cell carcinomas in dogs," J. Histochem. Cytochem. 49(7), 867-875 (2001).

47. Y. Kuge et al., "Synthesis and evaluation of a radioiodinated lumiracoxib derivative for the imaging of cyclooxygenase-2 expression," Nucl. Med. Biol. 36(8), 869-876 (2009).

48. D. R. Brocks and F. Jamali, "Etodolac clinical pharmacokinetics," Clin. Pharmacokinet. 26(4), 259-274 (1994).

49. N. M. Davies et al., "Clinical pharmacokinetics and pharmacodynamics of celecoxib: a selective cyclo-oxygenase-2 inhibitor," Clin. Pharmacokinet. 38(3), 225-242 (2000).

50. N. M. Davies and N. M. Skjodt, "Choosing the right nonsteroidal anti-inflammatory drug for the right patient: a pharmacokinetic approach," Clin. Pharmacokinet. 38(5), 377-392 (2000).

51. J. K. Takemoto et al., "Clinical pharmacokinetic and pharmacodynamic profile of etoricoxib," Clin. Pharmacokinet. 47(11), 703-720 (2008).

52. F. D. Hart and P. L. Boardman, "Indomethacin: a new non-steroid anti-inflammatory agent," Br. Med. J. 2(5363), 965-970 (1963).

53. J. N. King et al., "Robenacoxib in the dog: target species safety in relation to extent and duration of inhibition of COX-1 and COX-2," J. Veterinary Pharmacol. Therapeut. 34(3), 298-311 (2011).

54. Cancer Facts and Figures 2019, American Cancer Society, Atlanta, Georgia.

55. Oral Cancer Facts," The Oral Cancer Foundation, Newport Beach, California.

56. S. I. Mohammed et al., "Effects of the cyclooxygenase inhibitor, piroxicam, in combination with chemotherapy on tumor response, apoptosis, and angiogenesis in a canine model of human invasive urinary bladder cancer," Mol. Cancer Ther. 2(2), 183-188 (2003).

57. S. I. Mohammed et al., "Expression of cyclooxygenase-1 and 2 in naturally-occurring canine cancer," Prostaglandins, Leukotrienes, and Essential Fatty Acids 70(5), 479-483 (2004).

58. J. Y. Lee et al., "Expression of cyclooxygenase-2, P-glycoprotein and multi-drug resistanceassociated protein in canine transitional cell carcinoma," Res. Vet. Sci. 83(2), 210-216 (2007).

Biographies of the authors are not available. 